478 THE SECRETARY ON ADDITIONS TO THE MENAGERIE. [MIAY 16,

May 16,1871

Prof. Flower, F.R.S., in the Chair.

The Secretary read the following report on the Additions to the Society's Menagerie during the month of April 1871.

The total number of registered additions to the Society's Menagerie during the month of April 1871 was 215 , of which 13 were by birth, 99 by presentation, 92 by purchase, two by exchange, and 9 were received on deposit. The total number of departures during the same period by death and removals was 100 , showing a net addition of 115 individuals to the collection during the month.

The most noticeable additions were the following :-

1. A female of the new Deer which I have lately described and figured as Cervus alfredi (P. Z. S. 1870, p. 381, pl. xxviii.), received in exchange April 1st. This animal closely resembles the male in general appearance (except in the absence of horns), and is of very great interest, as confirming the validity of the species. I have also positive information as to its locality, this animal having been brought to England direet from the Philippines. Having a special article in preparation on this and the other known Deer of the Philippine Islands, I will defer saying more on this subject at present.

2. A second young one of the Collared Fruit-bat (Cynonyeteris collaris), born in the Gardens, April 7 th, and produced by the same pair as the former one, born in February last year (see P. Z. S. 1870, p. 127). The first young, which is a male, is still alive and doing well, keeping closely in company with its parents, and rather away from the other Fruit-bats in the same cage.

3. A young female Spider Monkey, purchased April 1 Jth. This animal was obtained at Colon by an officer of the $\boldsymbol{R}$. West-Indian Mail Co., and was stated to have been brought from the Atrato river by one of the American party now engaged on the survey of the isthmus for a ship-canal. It is of a uniform black, with the whole under surface of the belly pale fulvous, which colour, however, hardly extends on to the under surface of the limbs. The face and muzzle are flesh-colour. The hair is rough and upstanding, and appears to project forward on the forehead. It has no traces of an external thumb. It would appear to belong to the same group as Ateles variegatus, Wagner, but has no traces of a frontal band, or of white hairs on the sides of the face. I have been a little doubtful about this specimen, but on the whole am inclined to refer it to Ateles vellerosus, Gray*, with which it agrees more nearly than with any other described species.

4. A Geoffroy's Marmoset (Midas geoffroiit), purchased April 11 th, having been brought from Colon along with the Ateles just mentioned. Of this beautiful species, of which I exhibit a sketch

* Ateles vellerosus, Gray, P. Z. S. 1865, p. 733; Cat. Monkers, p. 44.

+ Hapale geoffroti, Puch. R. Z. I845, p. 336 . 


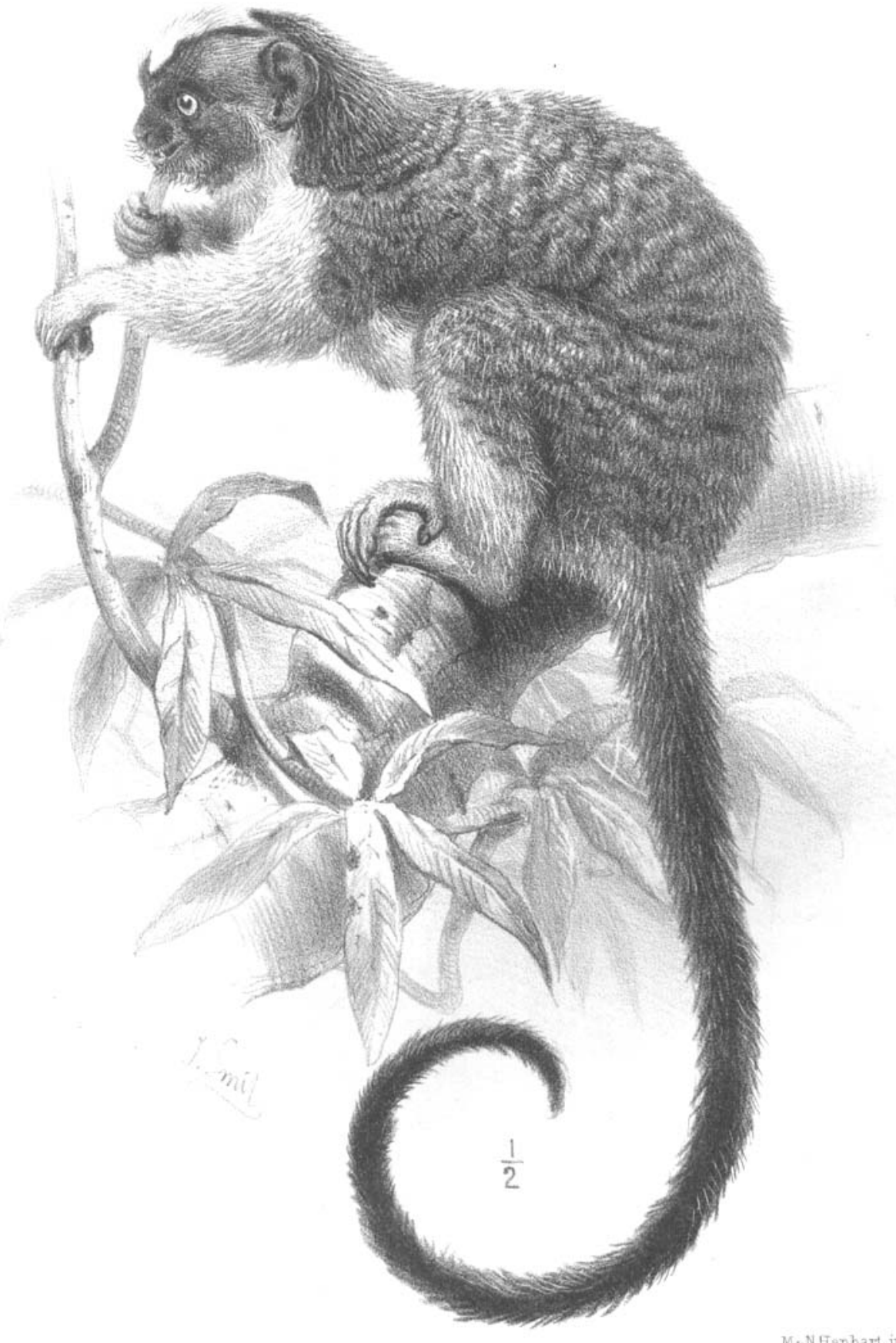


(Plate XXXVIII.) and the skin and skull (for the animal has since unfortunately died), specimens have, I believe, been once before living in the Society's Gardens. On "Sept. 26, 1857," I find entered in our register of accessions two "Titi Monkeys, presented by Julius Brenchley, Esq." These were determined by the then Secretary, Mr. Mitchell, as Midas ursulus*, but were, I have no doubt, Midas geoffroii, as the skin of one of them is now in the gallery of the British Museum, labelled as having been received from this Society about the same date under the name of the "Titi Monkey." Mr. Brenchley, in reply to inquiries on the subject, tells me that he obtained these animals "from the forests of New Granada, near the coast." Other specimens of this Midas in the British Museum were obtained by Mr. Salviu's collector Arcé at Chepo on the isthmus of Panama, so that there can be no doubt of this being its true locality.

5. Four Nose-horned Vipers, Fipera nasicornis (Shaw) †, presented by William Cleaver, Esq., of Cape-Coast Castle, West Africa, April 13th. Mr. Cleaver, writing March 17, informs me that three of these are "young specimens out of a batch of 21 born at CapeCoast Castle some few days ago-thus proving that the species is viviparous."

6. A Rat-tailed Serpent from Sta. Lucia (Trigonocephalus lanceolatus), presented by G. W. Des Vcux, Esq., C.M.Z.S., Administrator of the Government of the island. I am not aware that any example of this much-dreaded scourge of the West-India Islands has been previously brought to England alive.

The receipt of this and the previously mentioned donation renders our series of the true Venomous Serpents very full, as it now embraces specimens of Viperce nasicornis, rhinoceros, and arietans, Cenchris piscivorus, Trigonocephalus lanceolatus, Crotalus horridus and $C$. lecontei, besides the Elapine forms Naia hadje and N. tripudians.

7. 'Two Kiwis, purchased April 14th, one being of the ordinary species Apteryx australis + , and the other Apteryx owenni. As there remained only a single specimen of Apteryx (of the latter species) living in the Society's collection, this addition to our series is a very acceptable one.

8. A Bay Lynx (Felis rufa), said to have been brought from Mexico, purchased April 15th. 'This animal has very slender earpencils. A specimen previously in the Society's collection (purchased 26th June, 1868) with which it otherwise agrees, and of which I exhibit a sketch, is absolutely destitute of these appendages, and has caused me some perplexity, as I was not previously aware that the ear-tufts were ever absolutely deficient in any Lynx.

9. A pair of the little Hanging-Parrakeet of the Philippines (Loriculus culacissi), purchased April 24 ; and

10. An example of the Blue-crowned Parrot (Tanygnathus luco-

* Report of Council of the Z. S. 1858, p. 16.

† Strauch, Mém. Ao. St. Pét. ser. 7. vol. xiv., Syn. d. Vij. p. 88.

+ Tide infrà, p. 496. 
nensis) of the same islands. Both these beautiful species are new and welcome additions to the Society's extensive collection of living Psittacidæ.

A paper was read by Dr. P. Martin Duncan, M.B. Loud., F.R.S., F.G.S., Professor of Geology to King's College, London, \&c., entitled "A Description of the Madreporaria (Stony Corals) dredged up during the expedition of H.M.S. "Porcupine' in 1869 and 1870 .

This paper, which was communicated to the Society by Prof. Huxley, will be printed in the Society's 'Transactions.'

An extract was read from a letter addressed to the Secretary by Dr. R. A. Philippi, C.M.Z.S., Director of the National Museum of Santiago, dated Santiago, March 28th. In reply to inquiries of Mr. Sclater, Dr. Philippi stated that no Tortoise whatever had yet been found in Chili, and that the Tortoises forwarded to the Society from Santiago, upon which Testudo chilensis of Dr. Gray had been founded, had been, as already anticipated by Mr. Sclater (P.Z. S. 1870, p. 667 , and Ann. Nat. Hist. ser. 4. vol. vi. p. 470), collected by $\mathrm{Mr}$. Weisshaupt in the vicinity of Mendoza, Argentine Republic. Under these circumstances Mr. Sclater observed that the correct name of this Tortoise would be Testudo argentina, as suggested by him in the above-mentioned article in the 'Annals of Natural History.'

Monsieur Charles Dode, of St. Petersburg, exhibited specimens of some remarkable animals that he had collected during his recent travels in the Amour country, among which were particularly noticed specimens of the Long-haired T'iger (Felis tigris, var. amurensis), and of the Ounce (Felis uncia). M. Dode also exhibited four specimens of the Red-breasted Goose (Bernicla ruficollis) from Astrabad, on the borders of the Caspian Sea, and examples of some beautiful new species of birds recently discovered in Turkestan, the most noticeable of which were Turdus mystacinus, Passer ammodendri, and Pyrrhula incarnata.

M. Dode made the following remarks on these specimens :-

Felis tigris, var. amurensis.

Cette espèce féline qui habite sur les bords du $\mathrm{fl}$. Amour et du fl. Oussouri présente quelques différences avec le Felis tigris bengalensis ; poils plus longs, couleur moins foncée, bandes noires moins prononcées. Sans être très-commun, on le rencontre assez fréquemment soit dans les vastes forêts vierges qui bordent le fleuve, soit dans les grands roseaux des bords des lacs. Cette espèce féline, qui est propre aux tropiques, n'émigre pas et supporte très-bien les vingt et vingtcinq degrés de froid que ces contrées ont à supporter pendant deux à trois mois et quelquefois plus. Les conditions d'habitat sembleut aussi avoir eu une influence très-grande sur les mours de ce félin ; 
son caractère semble être devenu moins féroce que celui du tigre du Bengale; il n'attaque jamais, poursuivi il fuit, et ne se défend que lorsqu'il est blessé à mort. Il est à regretter que les vastes solitudes où il habite ne permettent pas d'étudier les mours d'une manière spéciale.

\section{Felis uncia.}

Cette espèce est assez commune dans le Turkestan où les peaux mal dépareillées du reste se vendent assez cher aux Chinois. Le spécimen que j'en ai rapporté provient des bords du fl. Amour et semblerait, d'après les dispositions des taches, être une variété du Felis uncia que l'on rencontre aux Indes et dans le Turkestan.

Passer ammodendri.

Cette jolie espèce de passereau a été trouvée par M. Severtzow naturaliste Russe dans les montagnes Célestes sur des plateaux d'un accès difficile ; les seules données qui m'aient été communiquées, c'est que pendant l'hiver qu'on se trouve, cet oiseau ne descend pas dans la plaine.

\section{TURdus mystacinus.}

D'après les renseignements recueillis M. Severtzow, qui a étudié ce genre sur plus de 100 exemplaires, a constaté que la différence qui existe avec le Turdus atrogularis n'est pas une différence d'âge ou de sexe. C'est un oiseau de montagne dont les mâles descendent peu dans la plaine, où (en hiver) la principale récolte a été faite. Tous les $T$. mystacinus ne sont pas facile à reconnaître de $T$. atroyularis du même sexe; leurs variations individuelles sont très-corısidérables, et quelquefois il en existe qui font hésiter pour leur détermination. Mais, ce qui est sûr, c'est que la coloration de la gorge et du jabot du T. mystacinus présente des différences individuelles bien plus considérables que ses variations d'âge, qui ont été anatomiquement reconnues aux organes sexuels, à la pneumaticité des $0 s$, à la dureté des tendons. Ayant égard à cela, l'auteur doute de la distinction spécifique, qui serait cependant évidente, si les caractères des exemplaires expédiés à l'étranger étaient constantes, mais ils ne le sont que dans certaines limites; il $\mathrm{v}$ a :

$1^{\circ}$. Le pur type T. mystacinus ; les mâles adultes la gorge également fauve, encadrée de deux rangées latérales de taches noires, formant moustache; mais beaucoup plus de noir à la gorge et au jabot que leurs femelles, toutes les taches noires étant plus fortes.

$2^{\circ}$. Le pur type $T$. atrogularis, dont je possède les deux sexes.

$3^{\circ}$. Beaucoup d'intermédiaires, tous femelles, à plastron clair de la gorge tellement tacheté, que ces mouchetures se confondent presque avec les moustaches, mais cependant plus claires que le jabot.

The following papers were read :-

Proc. Zool. Soc.-187I, No. XXXI. 
1. On Speke's Autelope and the allied Species of the Genus Tragelaplus. By Sir Victor Brooke, Bart., F.Z.S., F.R.G.S.

\author{
[Reeeived May 3, 1871.]
}

\title{
(Plate XXXIX.)
}

Some confusion apparently existing between three of the larger known species of the genus Tragelaphus, it has occurred to me as not entirely useless to review their history, and to endeavour to lessen the confusion, by giving characters of distinction between the species which may prevent similar mistakes in future.

In the 'Proceedings' of this Society for 1864 (p. 103, plate xii.) Dr. Sclater described and figured provisionally an Antelope, of which the horns attached to part of the frontal bones of an adult, and the skin and horns of a young male, had been brought from Karaguć by Captain Speke, on his return from the Victoria Nyanza. In the 'Proceedings' of the same year (p. 649) Dr. Kirk expressed his opinion that the "Nakong" of the marshy regions of Lake $\mathrm{N}$ 'gami and the Chobe was identical with the " $\mathrm{Nzoe}$ " of Karagué, the T. spekii of Sclater.

Dr. Sclater, being very desirous to throw as much light as possible on the history of this little-known and most interesting Antelope, subsequently collected some MS. notes on the subject, which be intended to form into a supplementary paper, more fully describing the species and its allied forms. These notes, however, he has lately, in the most generous manner, placed in my hands for consideration, knowing my special interest in this branch of zoology. Amongst these papers are two letters, one from Dr. Livingstone, the other from Mr. Oswell. Both of these gentlemen express themselves satisfied as to the identity of the "Nakong," procured by them during their visit to Lake N'gami in 1852 , with the " $N z o e$ " obtained by Capt. Speke in equatorial Africa. In a letter which I have just received from $\mathrm{Mr}$. Oswell, relative to the habits of the "Nakong" of Southern Africa, he remarks, "The colour of male and female is alike, a rusty blackish-brown; hair long and shaggy. This Antelope is scarce, in small families, though I am told more abundant on the swamps of the Teoghe river, N.W. of N'gami, and is not, I think, found short of the point where the Zouga river issues from the lake. It lives entirely in the swamps and reeds; and its feet are wonderfully adapted to its habitat; their extreme length and area of tread, including the fetlock up to the succentorial huofs, make them perfect 'swamp-shoes,' though they incapacitate the animal from rumning on hard ground. When pressed, the Nakong takes to the water, and sinks itself altogether save the nostrils; in this position it is often speared by the natives." Mr. Oswell adds, "my description must only be taken for what it is worth, as I think I only saw a Nakong once, and the 


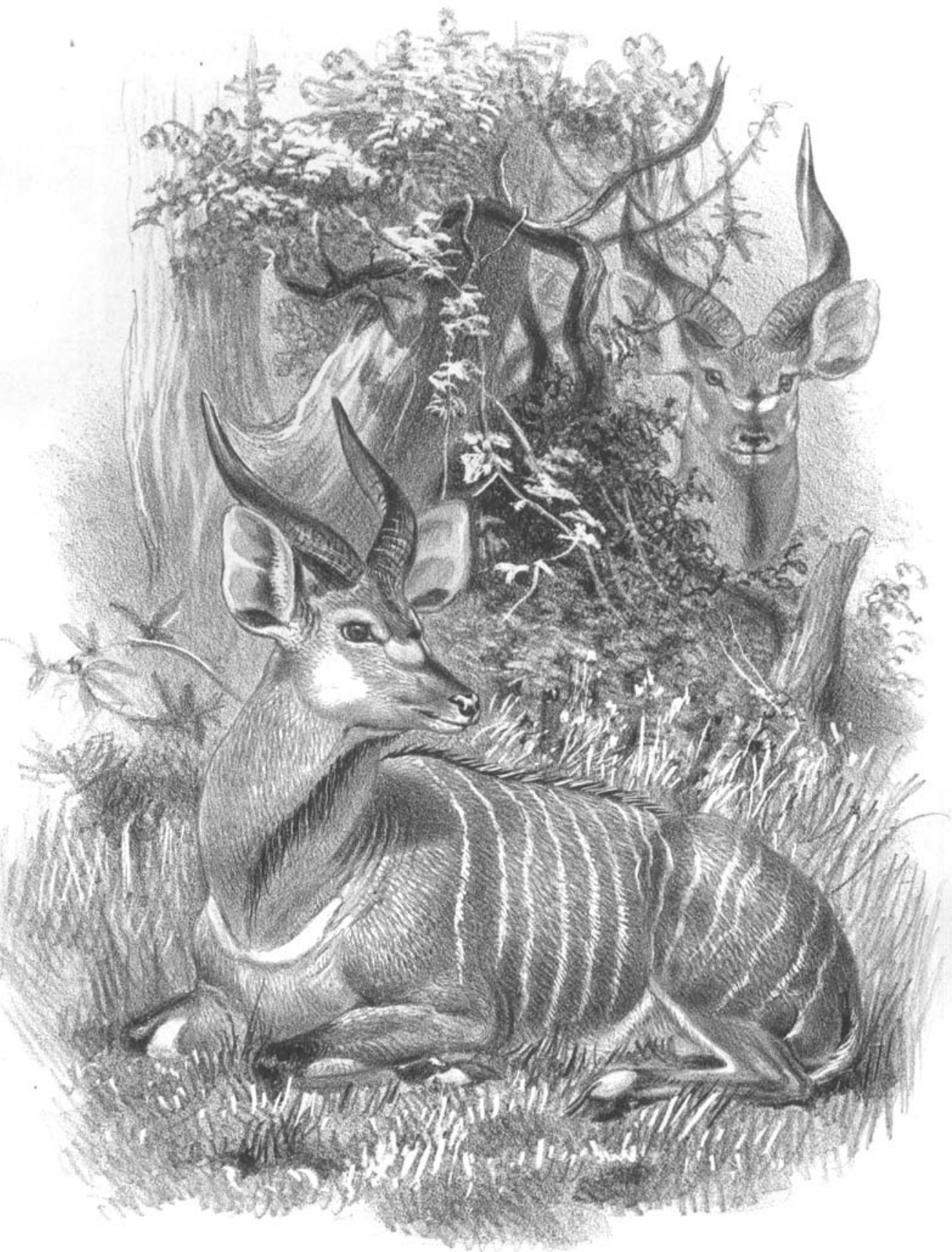


description of their hiding in the water, and inability to run on hard ground are entirely from native accounts."

Mr. Oswell has also most kindly, and I fear at considerable inconvenience, forwarded me for comparison the specimen brought by him from Lake N'gami.

The Nakong is mentioned by Mr. Baines in his 'Explorations in S.W. Africa' (p. 458), also by Mr. Andersson in his 'Lake N'gami' (p. 449). The latter brought home a damaged skin, and a sketch of the head, which he submitted to Dr. Gray for identification; but that gentleman naturally, owing to the meagre materials at that time at his command, expressed himself " unable to determine its exact nature, but seemed inclined to consider it identical with Tragelaphus euryceros"' (see 'Lake N'gami,' p. 449).

Being very desirous to arrive at some definite conclusion'concerning this Antelope and the two species of Tragelaphus, viz. T. euryceros and $I$. angasii, with which, I have reason to believe, it has been occasionally confounded, I have lately made a very careful examillation and comparison of all the heads and skins belonging to these three species that I could get access to, both in the British Museum and elsewhere ; and I must express my obligation to Dr. Gray for the courtesy with which he has afforded me every facility for examining the specimens under his care, and to Mr. Gerrard for the very great patience with which he has assisted me in that examination.

I will now describe the characters by which I believe the skulls and horns, the materials most commonly presented to our judgment in the case of the rarer Antelopes, may be, in case of the three species under consideration, at all times distinguished from each other. For the full description of T. spekii, see P.Z.S. 1864, p. 103; for that of T. angasii, P. Z. S. 1848, p. 89 ; and for that of T. euryceros, Proc. Soc. Nat. Hist. Bost. 1852, p. 299.

In the accompanying drawings, figs. 1 and 2 (pp. 486, 487) represent heads in my own collection, which specimens I have the pleasure of submitting for examination this evening. Fig. 3 (p. 488) is taken from the type specimen of $T$. euryceros in the British Museum, the skulls having unfortunately been destroyed in the case of my own specimens of this Antelope.

It will be seen that there is a most remarkable difference in size between these three Antelopes, $T$. euryceros being, roughly speaking, as much larger than $T$. angasii as that species is larger than $T$. spekii-the difference between $T$. euryceros and $T$. spekii being about equal to that existing between a Wapiti and a Fallow Deer.

The difference of mere size is so great that, had it been duly observed, it would have been, I think, impossible for confusion to have taken place between Antelopes differing so widely in this and many other features.

For the purpose I have in view, it is unnecessary to go into osteologieal details; but there are also, as may be observed, considerable differences in the form of the skulls - the most remarkable of which is, perhaps, the breadth of $T$. euryceros across the cheeks, a measurement taken from the most laterally projecting parts of the 
maxillæ bearing a much larger relative proportion to the general width of the skull in this than in the two other species.

The horns of these Antelopes, though bearing a strong family likeness, are, if looked at carefully, very easily distinguishable from each other.

The strength, decision, and spiral twist of the keels, standing as they do in inverse ratio to the size of the three species, give a widely different character to the horns at all ages, especially when we compare the massive and rather short horns of $T$. euryceros with the long, graceful, slender horns of T. spekii.

In colour and external surface the horns of $T$. angasii and $T$. spekii differ considerably, those of the latter, in all the specimens I have examined, being of greenish-brown colour, the annulations wide apart, smooth, and polished, with the posterior of the two keels which encircle the horns very strongly raised during its entire course, ruming strongly outwards as it nears the points of the horns, where it dies away. In $T$. angasii the horns are black, the annulations rough and closely set, and the posterior keel, though well marked at all ages, is much more indistinct and undecided than in T. spekii.

Between the horns of $T$. euryceros and $T$. angasii there exists so wide a difference that, if once their respective characters are observed, they cannut be mistaken for each other.

Besides the very great massiveness of the former, the anterior keel is almost, in some cases quite, obsolete, the surface of the horms, as in those of ' $T$ '. spekii, being greenish brown and very smooth, contrasting strongly with the black, crisp annulations of $T$. angasii.

My chief object in entering so particularly into the differences observable in the skulls and horns of these Antelopes is, in some degree, to substantiate the following interesting conclusion, relative to the distribution of Tragelaphus spekii, at which I have arrived after my observations on the subject. In the 'Proceedings' of this Society for 1848 (p. 88), there is a notice of an Antelope obtained by Capt. Allen during the Niger expedition at Kokki, on a small tributary (the Abo) of the Cameroons river, in the Bight of Biafra. In the Appendix to the 'Narrative of the Expedition to the Niger,' in 1841 , vol. ii. p. 488 , I find a reference to the same Antelope, with the statement that "Mr. Ogilby believed the horns to have been taken from $\boldsymbol{A}$. euryceros; but Mr. Mitchell, the Secretary of the Zoological Society, and Mr. Waterhouse, thought they might have belonged to an entirely new and undescribed species." The skull and horns of this individual are now, and have been for many years, in the British Museum. The specimen is mentioned in Dr. Gray's Catalogue of the Mammalia of the British Museum (p. 137) as var. 1 of T'agelaphus euryceros. I have most carefully examined it, and hare compared it with the type of Tragelaphus spekii, with the specimen of that Antelope in my own collection (fig. 1, p. 486), with a specimen in the British Museum, composed of the skin, horns, and feet, which specimen Mr. Layard recognizes as one sent by him from South Africa to M. Verreaux, and which passed from M. Verreaux into the British Museum, and with a frontal bone 
and horns brought by Mr. Green from Lake N'gami, and presented to the British Museum. The result of this comparison is, that I have no doubt that all these specimens belong to one and the same species. With respect to the Biafra specimen, I am confirmed by Capt. Allen's remarks on the subject. He says (P. Z. S. 1848, p. 88), "It was, I should think, about 3 feet high, or rather more, of a darkish brown colour." The locality where he obtained it he describes as "pestiferous and foggy," most truly characteristic of the resorts of this remarkable animal.

In still further corroboration of this opinion, I find a horn in the British Museum that I consider unquestionably to belong to this species, labelled "(Parzudalii) Gaboon," also a skin, horns, and feet, beyond any doubt of a Speke's Antelope, which specimen Mr. Gerrard informs me was sent by $M$. du Chaillu from Gaboon, in 1865, to Mr. John Murray of Albemarle Street, and brought by Mr. Gerrard from Mr. Murray's to the British Museum. Should the distribution of an Antelope so specially adapted to a life amongst swampy and marshy regions be found to extend from the Victoria Nyanza on the east to the Cameroon and Gaboon country on the west, and thence to Lake N'gami on the south, it will, I think, be a matter of some interest, as it will indicate the probability that large parts of unexplored equatorial Africa are suitable to the habits of this lake- and swamp-loving Antelope.

The following diagnoses* will, I hope, afford characters for distinguishing these three species of Tragelaphus:-

A. Hair of sides smooth and short, striped with white bands, descending from a white dorsal streak. Iloofs short.

a. General colour deep chestnut; stripes strongly marked, numerons. Horns smooth, massive. Neek, back, and belly maneless. Tail bovine. Fore limbs with dark

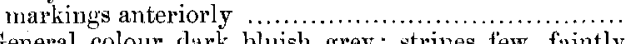

b. General colour dirk bluish grey; stripes few, finintly marked. Horns rough, moderate. Neck, back, and belly maned. Tail cervine and hairy. Fore limbs rich tan below the knees ............................. T. arigati.

13. Hair of sides coarse and long, without stripes. Hools long.

e. Generul colour rusty brown. Neck maned. Horns smooth, slender, strongly keded. Hair of sides and body of uniform length

The synonymy of these three species, so far as I have been able to examine it, appears to stand as follows:-

\section{Tragelaphus spekit.}

1848. Antelope from Bight of Biafra, Allen, P. Z. S. I848, p. 88. 1850. Strepsiceros, sp. ?, Turner, P. Z. S. 1850, p. 17l.

1852. Tragelaphus euryceros, var. I, Gray, Cat. Mam. B. M. 1852 , p. 137.

1856. Nakong, Andersson, Lake N'gami, p. 449.

* These diagnoses only apply to the males of ench species, the fomalts of $T$. enryceros and angasii being unkiown. 
1861. Tragelaphus euryceros?, Layard, Cat, Mamm. Afric. Mus. 1861, p. 79.

1864. Tragelaphus spelii, Sclater, P. Z. S. 1864, p. 103.

1864. Nakong, Baines, Expl. S. W. Africa, p. 458.

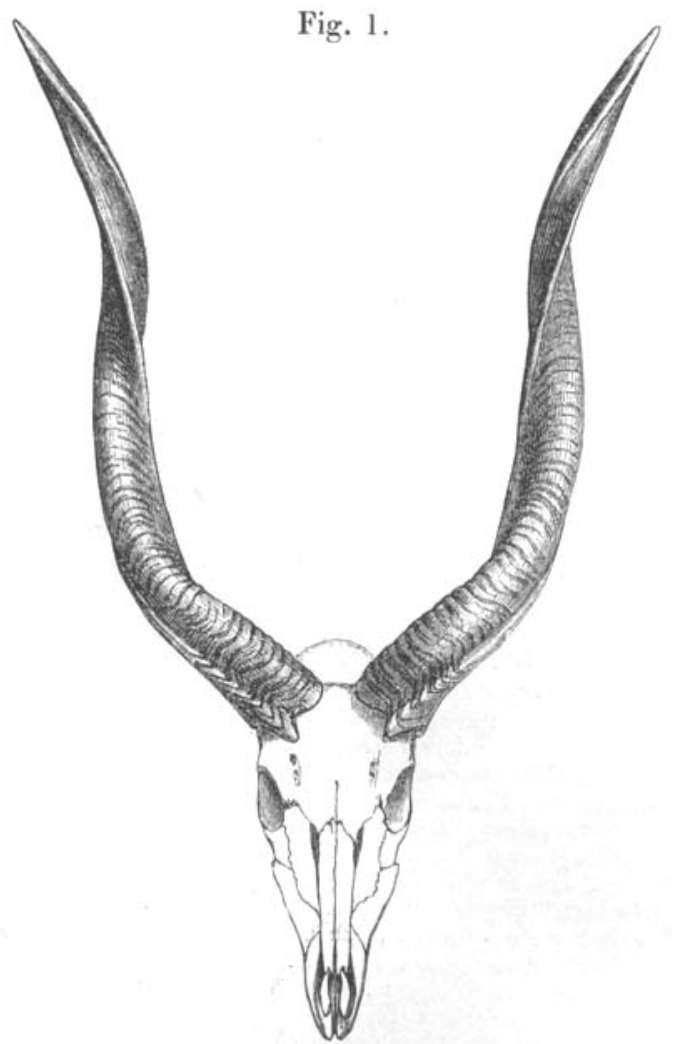

ITead and horns of Tragelaphus spekii, from specimen $g$ of list.

\section{Exact Localities and Authorities.}

Bight of Biafra (Allen); Lake N'gami (Oswell, in litt.) ; Karagué (Speke).

List of Specimens examined.

a. Type specimen of T. spekii, Sclater. Mus. Brit.

b. Skull and horns from Bight of Biafra. Mus. Brit.

c. Frontal bone and horns (T. angasii, $a$, in Cat. of the Bones in Brit. Mus. Gray, p. 246). Mus. Brit.

d. Single horn in Mus. Brit. (T. emyceros, $f$, Cat. Bones B. M. p. 246$)$. 
e. Skin with feet, frontal bone, and horns, "Du Chaillu, Gaboon." Mus. Brit.

f. Skin with feet, skull, and horns, from M. Verreaux. Mus. Brit. $g$. Skull, with horns attached. In my own collection.

$h$. Frontal bone, horns, and foot. In the collection of Mr. Oswell.

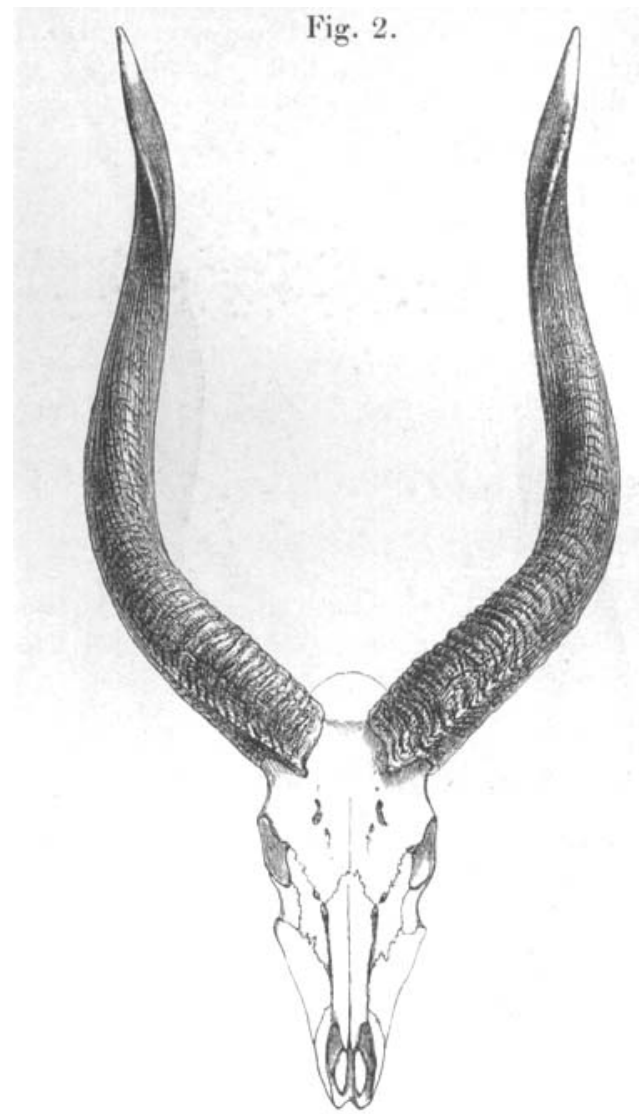

Head and horns of Trageholhes angusii, from specimen $d$ of list.

\section{Tragelaphus angasit.}

1848. Tragelaphus angasii, Gray, P. Z. S. 1848, p. 89.

1850. Tragelaphus angasii, Gray, Knowsl. Menag. p. 27, and P. Z.S. 1850 , p. 144.

1850. Strepsiceros angasii, Turner, P.Z. S. 18.50 , p. lï.

1850. Tragelaphus angasii, Proudfoot, P. Z. S. 1850, p. 199.

1852. Tragelaphus angasii, Gray, Cat. Mamm. Brit. Mus. 1852, p. 137.

1854. Inyola, Baldwin, African Hunting, 1854, p. 76. 
488 ON SPEKE'S ANTELOPE AND ALLIEd TRagelaphi. [May 16, Exact Localities and Authorities.

Mapoota River (Proudfoot); St. Lucia Bay (Angas, Baldwin).

List of Specimens examined.

a. o \& $\&$. Horns and skin. Mr. Fellows's collection.

b. Skin and homs, Mr. Eastwood, Pongi river. Mus. Brit.

c. Skin, skull, and horns. Mus. Brit. Locality?

r. Skull and horus. In my own collection.

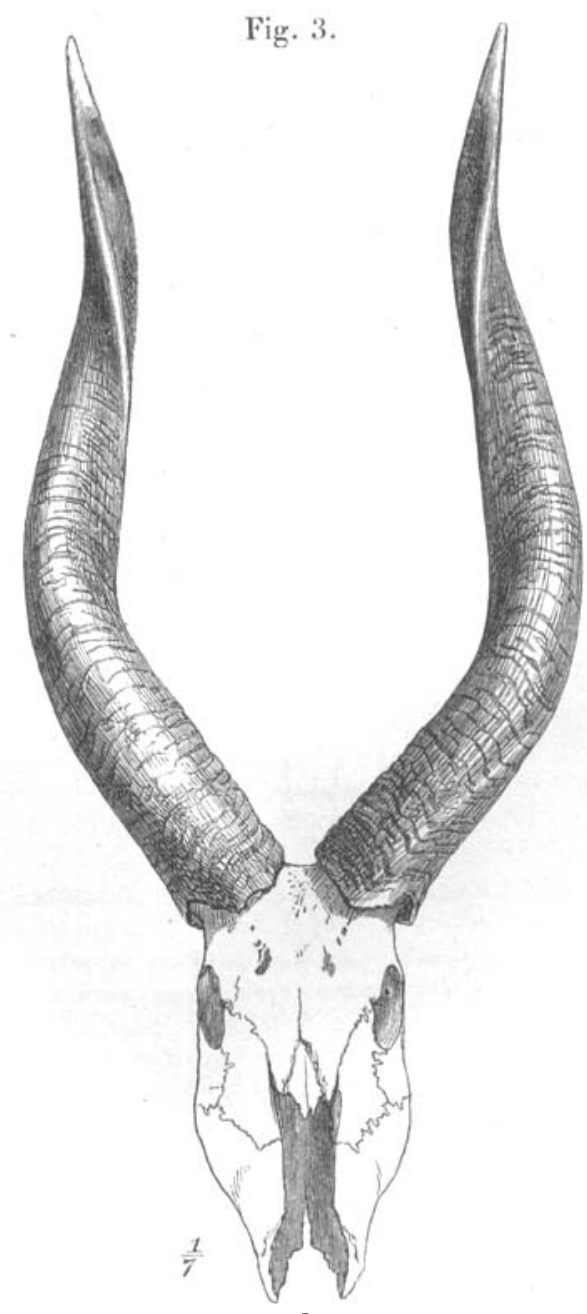

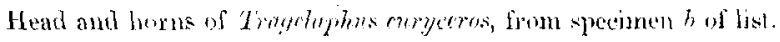


1871.] MR. P. L. SCLATER ON ANIMALS IN THE MENAGERIE. 489

3. Tragelaphus euryceros. (Plate XXXIX.)

1836. Antilope euryceros, Ogilby, P. Z. S. 1836, p. 120.

1850. Tragelaphus euryceros, Gray, Knowsley Menag. p. 27,

t. xxiii. f. 1, and P. Z. S. 1850 , p. 144 .

1850. Strepsiceros euryceros, Turner, P. Z. S. 1850, p. 171.

1860. Tragelaphus albo-virgatus, Du Chaillu, Proc. Soc. Nat. Hist. Boston, 1860, p. 299.

1861. Tragelaphus albo-virgatus, Du Chaillu, Expl. Equatorial A frica, p. 306 .

1861. Tragelaphus euryceros, Gray, P. Z. S. 1861 , p. 276.

\section{Exact Localities and Authorities.}

Ashkankoloo Mountains, 60 miles south of the equator, 140 miles from the coast ( $D u$ Chaillu).

List of Specionens examined.

a. Frontal bone and horns (T. euryceros, $b$, Cat. Bones B. Mus. p. 126).

Brit.

b. Skull and horns. Type specimen of T. euryceros. Mus. Brit.

c. Skin and skull of young male, figured Plate XXXIX. Mus.

d. Frontal bone and borns exhibited. In my own collection.

$e$. Frontal bone and horns. in my own collection.

2. Notes on rare or little-known Animals now or lately living in the Society's Gardens. By P. L. Sclatwh, M.A., Ph.D., F.R.S., Secretary to the Socicty.-Part II.* liirds.

[Received May 13, 1871.]

\section{Buceros corrugatus, Temm.}

In my notice of the Hornbills received from Malacca and Sumatra, (P. Z. S. 1870, p. 220), I identified one of them as Buceros gracilis of Temminck (Pl. Col. 535), having omitted to notice that this is merely the female of B. corrugatus of Temminck (Pl. Col. 531), as has been pointed out by Schlegel, Mus, de P.-B. Buceros, p. 9. We have once before had a male specimen of this fine species of Hornbill in the Gardens (see P. Z. S. 1868, p. 261).

27. Bucenos subcylindricus, Sclater, P. Z. S. 1870, p. 668, pl. xxxix.

Mr. Sharpe has lately furnished me with skins of $B$. cylindricus and $B$. fistulator from his collection, which have enabled me

\footnotetext{
* For Part T. Maummalis, see antè, p. 221.
} 
to make a closer comparison between them and the bird recently described under the name above given from the specimen living in our Gardens.

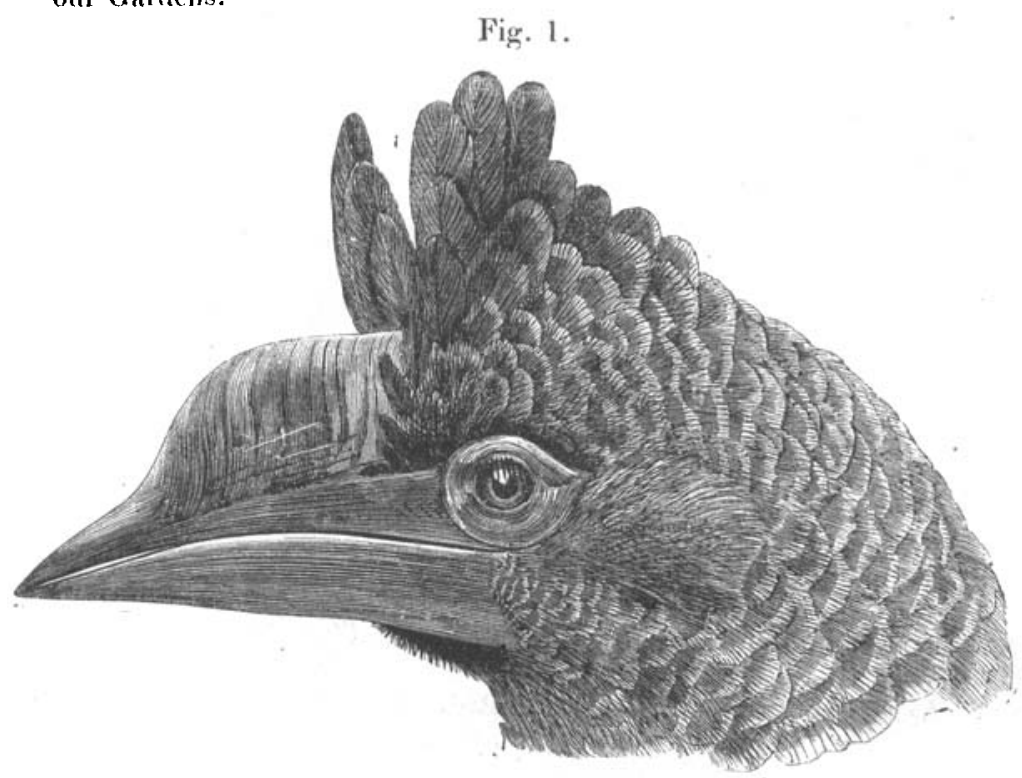

Tent of Bucpros subrylindrixus.

Buceros cylindricus is at once distinguishable by the peculiar form of the elevated casque, which is correctly figured by Temminck (Pl. Col. $52 \mathrm{l}$. fig. 2), and by the white tail being completely crossed by a black median band. Our bird, as regards the form of its bill, is, as shown by the sketch, much nearer to $B$. fistulator; but the culmen is more elevated than in $B$. fistulator, and the lower mandible not so strong. Moreover, in $B$. fistulator the culmen and tip and the base of the lower mandible are white; in our bird the whole bill is black. Again, in $B$. fistulator there are no signs of the terminal edgings on the crest, and the outer secondaries are black instead of white.

As far as I can at present make out, B. subcylindricus is distinct from both of these and from every other described species.

28. Cacatua gymnopis, sp. nov.

We have now placed next together in the Parrot-house three living specimens of three nearly allied species of the group of smaller white Cockatoos, the determination of which has caused me some little trouble, though they are obviously very distinct.

In the first of these birds (fig. 2), purchased April 11, 1864, being one of the individuals described in my notice, P. Z. S. 1864, p. 187 , and figured pl. xvii., there is no trace whatever of red colour 
on the face. The naked skin round the eye is nearly circular in form and of a pale blue colour ; the basal part of the crest-feathers is reddish orange, with a slight tinge of lemon-yellow towards their

\section{Fig. 2 .}

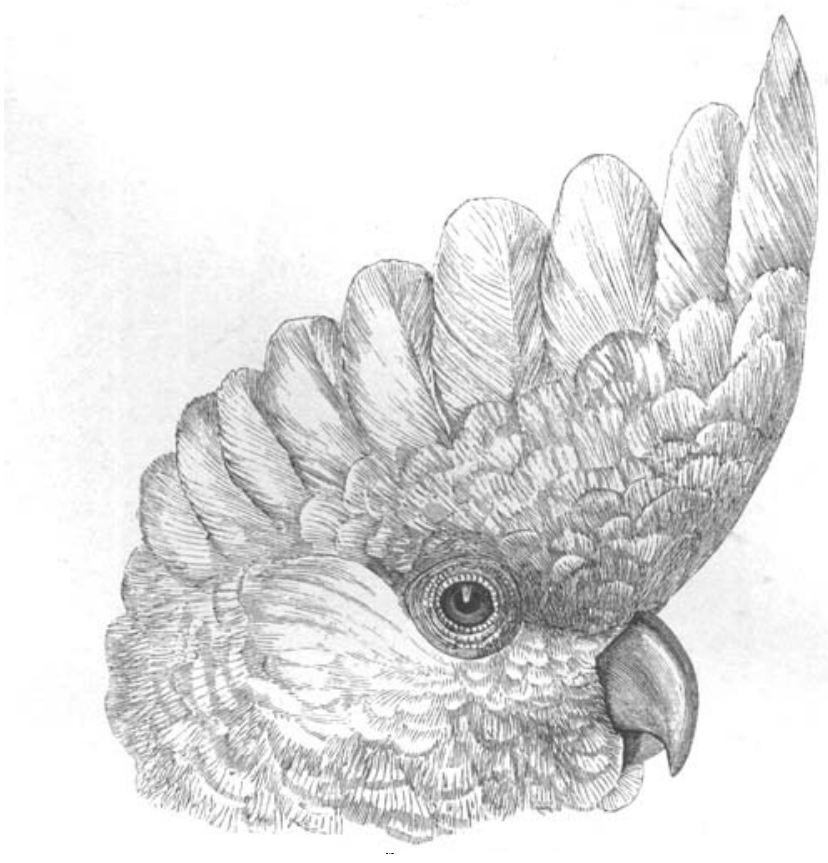

Head of cacatia drempsi.

summit, which colour, however, is hardly seen unless the crest is elevated. The wing- and tail-feathers are likewise stained in the inner webs with pale lemon-colour. This bird I take to be Cacatua ducorpsi, as already pointed out in my article above referred to, and as also determined by Mr. Finsch, who himself saw and examined the two examples of this bird which we originally received (cf. Finsch, Papag. i. p. $31 \mathrm{I}$ ).

In the second bird (fig. 3), which we obtained by purchase on the 25th November, 1865, the lores and front are tinged with reddish, and the crest is of a different shape from that of $C$. ducorpsi, having its front feathers much more elongated than those immediately behind them, so that when erected the crest is more pyramidal in form. The naked space round the eye is nearly circular as in C. ducorpsi, but white and not bluish. The crest-feathers are rosy at their bases, and there is no yellow in the crest; the inner webs of the wing- and tail-feathers are lemon-yellow. 'This bird I 
492 MR. P. L. SClater ON ANIMALS IN THE MENAGERIE. [May 16,

identify as Cacatua sanguinea, Gould, from Northern Australia, agreeing as it does in nearly every respect with his figure and with Dr. Finsch's excellent description (l,s.c. p. 307).

Fig. 3 .

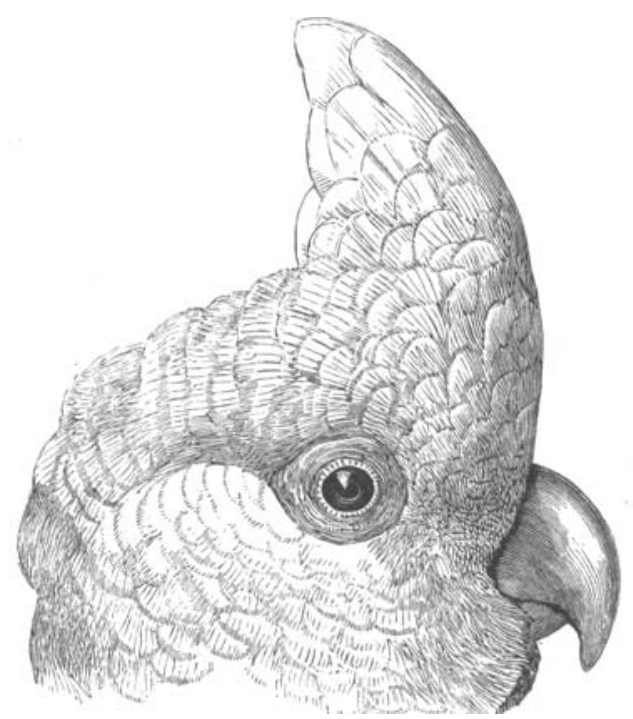

Head of Cacatua sanguinea.

The third of our smaller white Cockatoos has also the lores and front reddish, nearly as in $C$. sanguinea; but the usual naked space round the eye is largely extended into a bare open space below it, as shown in the accompanying figure (fig. 4), and is of a much deeper blue than in C. ducorpsi. In this respect the bird resembles Licmetis nasica more than any other Cacatua. The crest resembles in shape that of $C$. sanguinea above spoken of. The feathers on the head, neck, and partly on the belly are tinged with rosy red at their bases.

We purchased this bird of Mr. Jamrach on the 2nd of June, 1868. I determined it as $C$. goffini of Finsch, and so entered it in the register*; but after again going into the subject I am convinced that it cannot be that bird. Dr. Finsch gives as his diagnosis of C. goffini (Papag. p. 309), "loris rubris nullis," which cannot be reconciled with our bird; and does not mention the peculiarity of the large naked space below the eye, which could not have been passed over by so accurate an observer, especially when he had seen the bird alive.

I am therefore, somewhat unwillingly, compelled to give a new * Soe P. Z. S. 1868, APp. p. 645. 


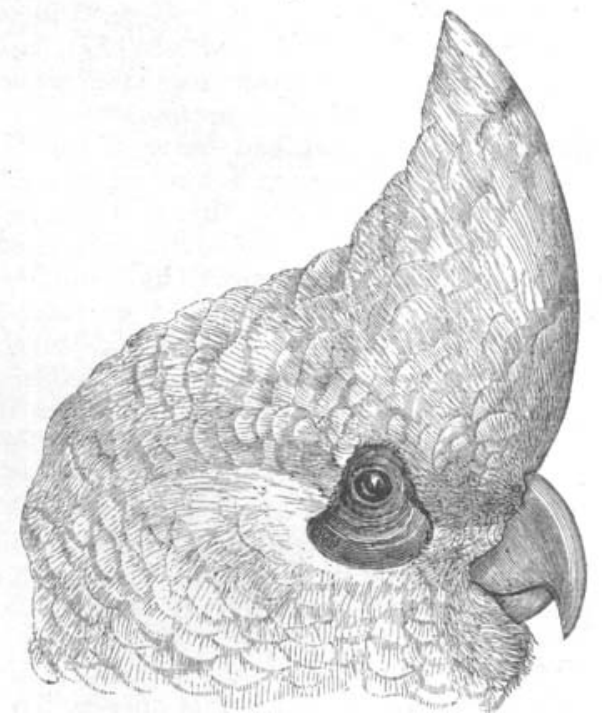

Head of Cacatua gymnopis.

name to our last mentioned bird, and propose to call it, from the large naked space below the eye,

Cacatua grmnopis, sp. nor.

Alba: fronte et loris rosaceis : regione ophthalmica nuda, infra dilatata, carulescenti-plumbea: crista pyramidali: plumis capitis cervicis et ventris ad basin rosaceo tinctis : remigibus rectricibusque intus limonaceo-flavescentibus : crassitie eam $\mathrm{C}$. sanguineæ paulo superante.

IIab. South Australia.

Viv. Soc. Zoolog. Londinensis.

[Obs. Since preparing these notes I have noticed that the two Cacatue in the gallery of the British Museum, obtained by Sturt at Depot Creek during his expedition into Southern Australia, and marked Cacatua sanguinea, evidently belong to the present species, (cf. Sturt's Narrative, vol. ii. Appendix, p. 36). The correct locality of the bird will therefore be the interior of South Australia.]

\section{Conurus kruginosus.}

In his excellent monograph of the Parrots (i. p. 506) Dr. Finsch has united the Psittacus ceruginosus of Limnæus (Syst. Nat. i. p. 142) along with a number of other synonyms (Conurus xantholemus, mihi, C. chrysogenys, Souancé, and C. ocularis, Scl. et Salv.) into one species under Conurus pertinax. I am not now quite in a 
494 MR. P. L. SClater ON ANIMALS IN THE MENAGERIE. [May 16,

position to discuss the correctness of all these identifications ; but as regards Ps. aruyinosus, which was founded primarily upon Edwards's "Brown-throated Parrakeet" (Birds, iv. $p l .177$ ), I think there can be no question that Dr. Finsch is in error in considering this, as he does (l. c. p. 507), the young of $C$. pertinax.

Since September 1866 we have had living in the Gardens two specimens of Conurus aruginosus, as I have always termed them, which were presented to the Society by Mrs. C. Vinall on the 21 st of that month. These birds have still the bluish cap and brown throat. characteristic of C. aruginosus, as portrayed in Edwards's figure, and have not acquired any yellow on the head or lace. There are merely some slight indications of a few yellow feathers round the eye. I have two skins, exactly similar, in my own collection, one of a bird formerly living in the Society's Gardens, which died in December 1866, and the other collected at S. Esteban in Venezuela, by Mr. Goering*. Mr. Salvin has a precisely similar specimen, lately obtaiued by Mr. Wyatt at Cienaga, in the valley of the Magdalena.

Under these circumstances I think that Conurus aruginosus must be restored to its position in the genus, as Mr. Salvin and I have already attempted to show, P. Z. S. 1867 , p. 588.

\section{Psittacus timneh, Fraser.}

As Dr. Finsch, although admitting this species, has stated that he nevertheless believes it to be only the young of Psitt. erithacus, I think it right to state that the example of this species acquired by the Society in February 1861 is still living in the collection, and has not changed in the least; so that there can be no question, 1 think, of its being quite a distinct species.

Mr. Bartlett tells me he has seen numbers of the Timneh Parrot in the hands of dealers, and that it is perfectly well known as a distinct species.

\section{Tanygnathus albirostris, Wallace.}

In March 1868 we purchased the first living specimen I had ever seen of this species, as already recorded in the Society's 'Proceedings' (1868, p. 262). In August 1869 we purchased a second; and a third individual of the same form is now living in the Society's Gardens.

I must say that, so far as I can tell from an exarnination of the living birds, I am inclined to agree with Mr. Wallace (P. Z. S. 1862, p. 336) in considering this bird specifically distinct from $T$. muelleri, of which we have had several living examples. It is at once recognizable by its white bill.

\section{Buteo auguralis, Salv.}

Two Buzzards, purchased April 26, 1866, and believed to have been received from West Africa, were named by me Buteo augurt, and thus inserted in the Society's register. Mr. Gurney, however, to whom we owe many thanks for the trouble he takes in the correct

\footnotetext{
* Soe P.Z.S. 1862, p. 6i32.

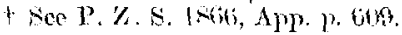


determination of the raptorial birds in the Society's collection, after a careful examination decided that they were referable to the allied species described by Dr. Salvadori in 1865 as Buteo auguralis (Atti Soc. It. viii. p. $37 \dot{6}$ ) ; and I have altered the name in the new List of Animals accordingly.

33. Spllornis bacha, Daud.

In May 1865, Mr. A. Grote sent home to us from Calcutta two young specimens of a bird-of-prey of the genns Spilornis, received by him from the Andaman Islands, and considered to be typical of "Hamatornis elgini, Tytler," as described by Blyth, J. A. \$. B. xxxii. p. 87 (1863), and 'Ibis,' 1863, p. 118.

These birds lived long in the Gardens, and were constantly examined by Mr. J. H, Gurney, who eventually purchased one of the dead specimens for the Norwich collection. Mr. Gurney pronounced them to be without doubt identical with Spilornis bacha (Daud.) of the Malay countries. I think it right to call attention to this, as in his list of Andaman birds, published in 'The Ibis' for $1867, \mathrm{Mr}$. Beavan has stated that the specimen received by us from $\mathrm{Mr}$. Grote was referable to Spilornis cheela of India-an error subsequently corrected by Mr. Blyth (Ibis, 1868, p. 131).

It would appear therefore that both $S$. cheela and $S$. bacha occur in the Audaman Islands.

34. Crossoptilon mantchuricum, Swinhoe.

In the last edition of the List of Vertebrates (p. 141) and hitherto generally I have called this bird Crossoptilon auritum (Pall.). But from what Mr. Swinhoe informs me there seemed to be little doubt that the newly described Crossoptilon ccerulescens of Père David (C. R. lxx. p. 538) will turn out to be the true Phasianus auritus of Pallas; and we must therefore adopt for the present bird Mr. Swinhoe's alternative name mantchuricum, proposed P. Z.S. 1862, p. 286. The genus Crossoptilon will therefore now comprehend four species:-

1. C. tibetanum, Hodgson, from Eastern Tibet.

2. C. drouyni, Milne-Edwards, C. R. April 20, 1868, from Western Szechuen.

3. C. auritum, Pallas, from the Gobi Desert.

4. C. mantchuricum, Swinhoe, from China, north of Pekin.

As regards our living specimens of the latter bird, I regret to say that our hopes of introducing this fine bird permanently into Europe appear likely to be miserably disappointed. Nearly all those in our Gardens, both introduced and bred, alike have sickened and died, and at the present moment we are left with two females only. In most of the Continental gardeus, so far as I can make out, nearly the same event has taken place.

35. Numida edouard, Hartl.

Last year, as recorded in these 'Proceediugs' (1870, 1. 383), we furchased of the Sucicté Zoologique d'Acelimatation a pair of 
Crested Guineafowls, which were the types of Mr. Elliot's new species Numida verreauxi (Ibis, 1870, p. 300, and Monogr. of Phas. pt. i. pl. 16). I am, however, informed by M. Jules Verreaux that they are of the same species as that previously dedicated by Dr. Hartlaub to the late M. Edouard Verreaux as Numida edouardi (Journ. f. Orn. 1867, p. 36). The latter name has naturally precedence.

36. Larus atricilla, Linn.

In April last year we purchased of a dealer two Gulls in immature and dirty plumage, stated to have been received from "New Zealand." Relying, somewhat too confidently I confess, on this locality, I entered them in the Register of Additions as Larus melanorhynchus, Buller*, that being the only species in the list of New Zealand birds likely to suit them. One of them died, but the other moulted into fine plumage this spring, and has put on a beautiful black hood, dark mantle, and other characteristics of the well-known North-American species Larus atricilla.

I am not aware that we have previously had a living specimen of this bird in the Society's collection.

37. Apteryx nustralis, Shaw.

The Apteryges living in our gardens have hitherto been referred to A. mantelli, Bartlett. Having, however, lately had an opportunity of examining a series of specimens, $I$ find that there is a large amount of individual variation among them, particularly as regards the scaling of the tarsus, and have nearly come to the conclusion that there are only two species of the genus yet properly discriminated, namely Apteryx australis (embracing all that we have hitherto called A. mantelli) and $A$. oweni. Of the distinctness of these two species (both of which are now represented in our living collection) there can, I think, be no possible doubt.

3. On the Birds of the Vicinity of Lima, Peru. By P. L. Schater, M.A., Ph.D., F.R.S. With Notes on their Habits; by Professor W. Nation, of Lima, C.M.Z.S. (Part IV.†).

[Received April 26, 1871.]

Various circumstances have unfortunately hindered our corresponding member Professor Nation for some time past from continuing to transmit to me his collections and notes. He has, however, lately found an opportunity of sending me a few skins, accompanied by the following remarks:-

1. Phrygilus alaudinus (Kittlitz); Sclater, Cat. A. B. p. 111. "In 1867 I discovered this beautiful bird on a large plain, covered

* See P.Z. S. 1870, App. p. 895.

1 Continued from P.Z.S. 1869 , p. 148. 
with low bushes, a few miles from Lima. It was feeding on the ground, after the manner of a Zonotrichia. Subsequently, I have made hundreds of visits to this plain, and have shown the example to many sportsmen, but have neither seen it again myself nor been able to obtain any information respecting it. I am therefore of opinion that its occurrence in this plain was accidental, and hope to discover its true abode in some of the valleys of the Andes."-W. N.

Mr. Nation calls this bird "erythrorhynchus, Lesson," referring it to the Fringilla erythrorhyncha of Lesson (Journ. de l'Inst. 1834, p. 316 ; et Zool. Thétis, ii. p. 324). This is doubtless correct; but the name of Kittlitz, usually employed, is older (1832).

This bird ranges from Chili as far north as Ecuador, where Fraser met with it on the plateau of Riobamba.

2. Spermophila telasco, Lesson; Sclater, Ibis, 1871 , p. 7.

"This is a very familiar and social little bird, frequenting our gardens, orchards, and road-sides, and associating with $V$ olatinia and Zonotrichia. The nest is usually in a low bush near the road-side or garden-walk. The eggs are three in number, of a pale greenish blue, irregularly marked with brown. This bird feeds on seeds and insects. Its jrides are bluish black. The plumage of the sexes has no perceptible difference." $-W$. N.

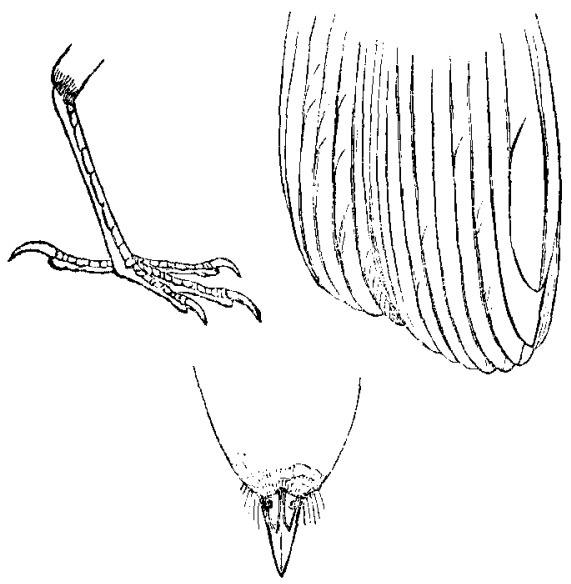

Euscarthmus fulviceps.

3. Euscarthius fulviceps, sp. nov.

Fuscus : pileo toto et capitis lateribus fulvescenti-rufis : alarum marginibus externis pallidioribus fere ochraceis : subtus albus, pectoris lateribus cinereo perfusis : subalaribus limonaceoflavis: remigum marginibus internis rufescenti-ochraceis : rostro superiore fusco, inferiore albicante: pedibus obscure car-

Proc. Zool. Soc.-1871, No. XXXII. 
neis: long. tota $3 \cdot 8$, ala $2 \cdot 75$, cauda $1 \cdot 4$ : cauda vix rotundata, alis brevibus, remigibus tertio quarto quinto et sexto fere aqualibus.

Hab. Vicinity of Lima (Nation); Babahoyo, Western Ecuador (Fraser).

Amongst the birds collected by Mr. Fraser in Ecuador was a specimen of a small Todirostrum-like species, shot at Babahoyo in August 1859 , which from its bad condition I was unable to determine, and entered in my list of his collection (P.Z.S. 1860, p. 283) as Todirostrum, sp.? In my American Catalogue (p. 209) I associated this specimen with another imperfect skin of a bird of the same group previously obtained by Fraser at Nanegal (P. Z. S. 1860, p. 93), but, I now believe, erroneously; for I subsequently convinced myself that the Nanegal skin was merely Euscarthmus squamicristatus (Lafr.) in young plumage. But Mr. Fraser's Babahoyo skin is certainly the same as that of which Professor Nation now sends an excellent skin from Lima.

$\boldsymbol{E}$. fulviceps seems to be distinguishable from all other members of the genus that $\mathbf{I}$ am acquainted with by its fulrous head. Mr. Nation sends me the subjoined note on it.

"In $1869 \mathrm{I}$ discovered this interesting little Tyrant in an Acaciagrove, situated between a marsh and the sea-shore, about ten miles from Lima. Subsequently I have visited this place many times, and have always found a few of these birds in company with individuals of Eupsilostoma in the extremities of the branches; but, as far as I know, it is not met with elsewhere in this district. Its habits so much resemble those of the Eupsilostoma that for many ycars I confounded the two species together.

"The food of this bird consists of sedentary insects. Its irides are brownish black." -W. N.

4. An.eretes albocristatus (Vig.); Sclater, Cat. Am. B. p. 212.

"This beautiful little tyrant is only an accidental visitor in the vicinity of Lima. One Sunday afternoon, in December 1868, I saw three individuals of this species in an Acacia tree overhanging a river. On the following morning I succeeded in finding them in the same tree and in shooting one; in the course of the week following I managed to obtain the other two. The birds proved to be an adult female and her two young ones. They were very restless, and continually moving from one twig to another. The food of this species appears to be exclusively insects. The irides are brownish blue.

"On the 8th of February, 187I, I again found this species, sixty miles up the siver, at an altitude of 3000 feet." $-W$. N.

5. Amazilia Pristina, Gould.

"As I write an Amazilia pristina has been sitting perched on a plant in the garden outside my window, singing delightfully at intervals. Rhodopis vesper, Thaumastura cora, and Th. francesca seem to be silent species."-W. N. 


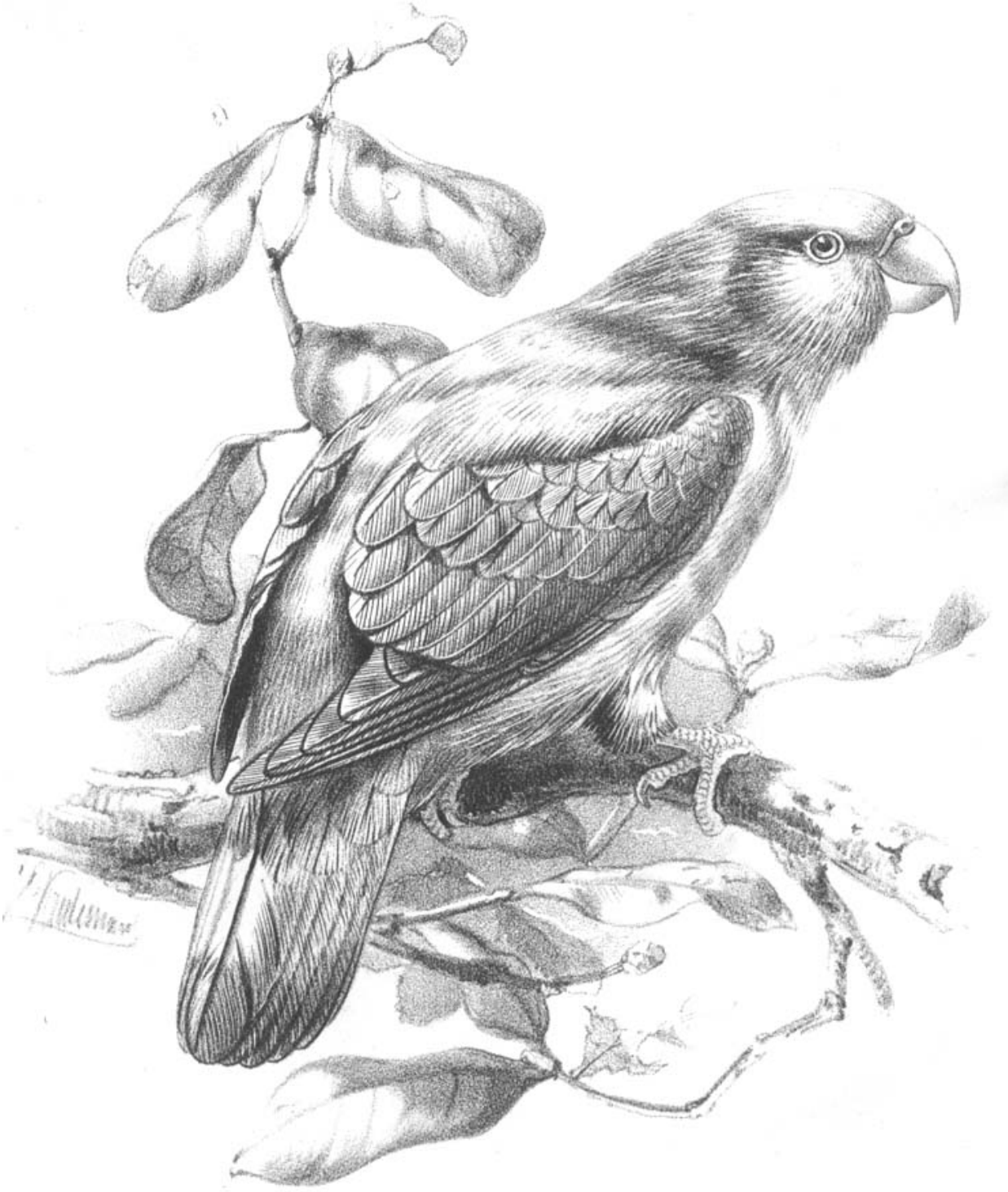

M \& N Hashart inte 


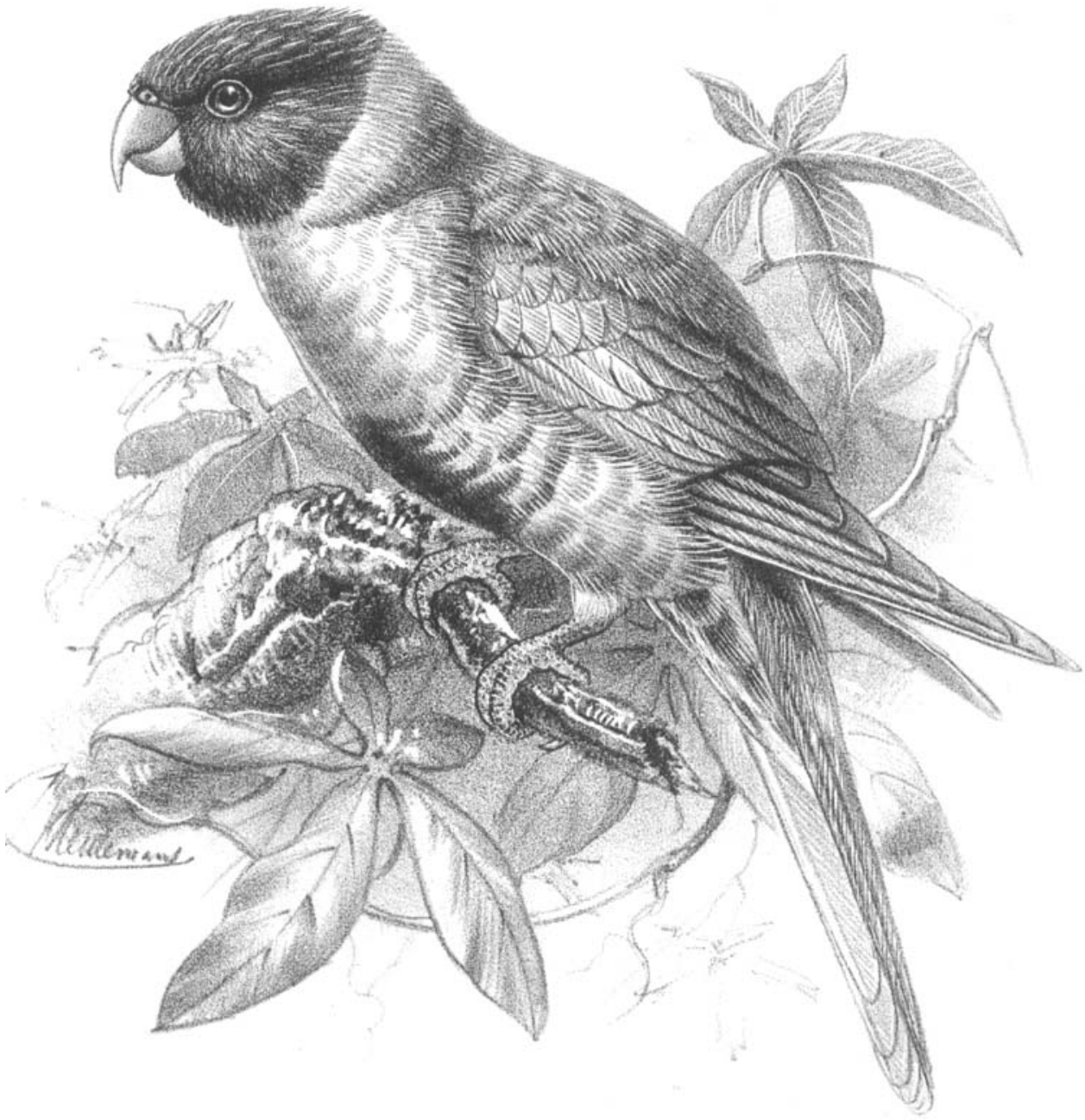


4. On two new or little-known Parrots living in the Society's Gardens. By P. L. Schater, M.A., Ph.D., F.R.S., Secretary to the Society.

[Received May 16, 1871.]

\section{(Plates XL, \& XLI.)}

The Society's collection has been recently augmented by the receipt of a certain number of animals, obtained by Mr. William Jamrach in the markets of Calcutta, several of which are of much interest. Of these I shall speak more fully in my next report on the additions to the Society's Menagerie. But I wish to lose no time in calling attention to the fone additions to the Society's series of living Psittacidæ, belonging to the species of the genera Lorius and Trichoglossus. The first of these, which appears to be undescribed, I propose to characterize as follows :-

Lorivs mibialis, sp. nov. (Plate XL.)

Coccineus: alis extus viridibus: campterio alari et subalaribus cyaneis : remigibus subtus flavissimis : semitorque pectorali obsoleta, fava: cauda coccinea, dimidio apicali nigricante : tibiis cyaneis: rostro clare aurantiaco, pedibus pallide carneis: unguibus corneis.

Obs. Species forma et crassitie Lorii garruli, a quo differt plaga interscapulii nulla, semitorque pectorali flava et tibiis cyaneis.

Only a single example of this fine new Lory was brought home by Mr. Jamrach. It was doubtless originally procured from one of the less explored islands of the Molucca group, which is rarely visited by traders. A slight irregular spotting on the wing is probably due to individual variation.

Along with this Lory we obtained a specimen of a small species of Trichoglossus, which I at first supposed to be also new. I am now, however, inclined to believe it to be referable to Trichoglossus mitchelli, G. R. Gray (Finsel, Papag. ii. p. 858). The only previously known specimen of this species, now in the British Museum, was likewise formerly living in the Society's Gardens.

Mr. G. R. Gray has kindly sent me the following notes, made on comparison of the drawing of this bird (Plate XLI.) with the typical specimen of $T$. mitchelli in the British Museum :-

"Your drawing of $\boldsymbol{T}$. mitchelli is not quite like the BritishMuseum specimen, as the following particulars of our example will, I think, show you, viz. :-Head, cheeks, and throat have a tendency to blue in some lights; frontlet with a narrow azure-blue band; cervical band is more yellow; the dark blue-black is on the green below the broad crimsou band on breast; the latter has sonre: indications of very narrow bands of yellow or of green; the yellow 
on the sides above the thighs and under tail-coverts is less prominent; the thighs are bright yellow; the under surface of tail-feathers a dull yellow; the outer web of first quill pure black."

\section{On Macharhamphus anderssoni.}

By R. B. Sharpe, F.L.S., Librarian to the Society.

[Received April 11, 1871.]

By Lord Walden's kind permission I am enabled to exhibit tonight one of the very rarest of Accipitres, the Macharhamphus alcinus, from Malacea ; and I take the present opportunity of giving; a history of the two species of Macharhamphus now known, as great confusion exists as to the question of their specific identity.

In the lst volume (1848) of the 'Bijdragen tot de Dierkunde,' which forms the 4to publication of the Zoological Society of Amsterdam (Natura Artis Magistra), Dr. G. F. Westerman described a birl from Malacca which he cailed Macharhamphus alcinus, making it the type of a new genus and species. The typical specimen, which was placed, and is still to be seen in the Museum at Leyden, remained unique for many years, till in 1865 the late Mr. Andersson sent to Mr. Gurncy a bird which the latter gentleman believed to be new to science, and to which he therefore gave the name of Stringony $x$ anderssoni, after its discoverer. This was descrihed at a Meeting of this Society on the 14th of November, 1865 ; but on the 12 th of $\mathrm{J}$ une in the following year Mr. Bartlett made some remarks on the specimen, which he believed to be the previously described $M$. alcinus of Dr. Westerman, supposing the latter gentleman to have made an error in the locality whence his example came. The way that $\mathrm{Mr}$. Bartlett accounted for the mistake was in this wise. In 1852 he received a collection for sale from the late $\mathrm{Mr}$. Andersson, which was the first consignment of that excellent collector to this country. This collection, or rather the remnant of it, was described in the 'Contributions to Ornithology,' by Messrs. Strickland and Sclater (l. c. 1852, p. 14l). After stating that the birds had been sent to "Mr. A. D. Bartlett, of London, for sale," Mr. Strickland proceeds : - "Unfortunately, as too often happens in such cases, many of these birds were dispersed before any catalogue was made of them. Some were purchased for the British Museum; others were bought by Mr. Frank, a dealer in Amsterdam; and of the residue about 100 specimens have passed into my possession." It so happened that Mr. Gurney asked Mr. Bartlett, who is, as we know, one of the best taxidermists in the world, as a favour, to stuff the Damara specimen of Stringonyx for the Norwich Museum, to which Mr. Gurney had presented it; and no sooner had Mr. Bartlett seen the specimen, than he called to mind a similar bird which he had once before possessed. This was of course the identical type of Macharhamphus; and 
Mr. Bartlett, remembering that at the time the Damara birds were bought a great number of Malaccan specimens were also purchased, concluded that the collections had been mixed, and that thus the Damara bird had come to be credited with a Malaccan habitat. Acquiesing in Mr. Bartlett's identification, Mr. Gurney sunk his proposed name of Stringonyx anderssoni, and his specimen was figured in the 'Trunsactions' as Macharhamphus alcinus. 'Thus the matter remained till the year 1868, when in Mr. Andersson's last collection another specimen was sent home, and passed into the National collection, where it now remains. Mr. Gurney requ'sted me to send him my opinion upon the specific identity of this last specimen with the figure of $M$. alcinus $(l . c$. .). I therefore took up the subject, and I found that the bird sent by Mr. Andersson was identical with the one previously transmitted by him and figured in the 'Transactions' (l.c.); but the absence of a crest in both these birds, added to a white eye-ring and abdomen, which did not appear in the Malaccan bird, induced me to suggest to Mr. Gurney the possibility of their being distinct species, while, from an examination of the figures of the tarsi given in the respective works above quoted, I inclined to believe in their belonging really to two distinct genera. Mr. Gurney shortly after visited Leyden; and having critically examined the Damara bird in the British Museum before starting, he told me on his return that he fully believed in its specific and generic identity with the type of $M$. alcinus at Leyden. Acquiescing at once in the opinion of so distinguished an authority on Accipitres as Mr. Gurney, I allowed the subject to drop for a time, till all my doubts were agaiı revived by my friend $\mathrm{M}$. Jules Verreaux, to whoin I referred the controversy during his recent sojourn in England, when he informed me that I was quite right in insisting on the specific distinctness of the two species, for that he had lately seen both old and young birds of the true $M$. alcinus from Malacca in Count 'Turati's collection. This information urged me once more upon the scent; but I was unable to discover any new facts bearing upon the subject, till in a recent collection formed by the late Dr. Maingay at Malacea, which has passed entire into Lord Walden's hands, I was delighted to perceive at last a specimen of $M$. alcinus. Thus the question was solved as far as regards the correctisess of the habitat; and on comparing the specimen lately received with the Damara bird in the British Museum, I am able to state the following facts. Although the legs are damaged in the Damara bird, there is, so far as we can see, no real difference in the scaling of the tarsi, as would appear from the figures given in the works before mentioned; so that Mr. George Robert Gray and I quite agree that, beyond the occipital crest in the Malacean bird (which it is not yet proved that the Damara species, when adult, does not assume), the two species cannot be generically separated; and I am glad to have had this veterau ornithologist at my elbow, as it is a bold thing to assert the absolnte similarity between two genera belonging to such widely distant localities. As regands specific characters we both agree that the birds are quite distinet. 
The Malaccan species coincides with the Damara bird in the form and style of plumage, having the white ring round the eye and the stripe down the throat, but differs in its larger bill, darker colours, brown abdomen, and long oceipital crest. There seems, however, to be a difference in the white feathers round the eye. $M$. anderssoni has a white superciliary line and a white spot below the eye $M$. alcinus has the latter plainly mottled, but has no distinct supercilium, though the feathers round the rim of the eye are whitish. Thus it will be seen that the Damara species must be restored under the name of Macharhamphus anderssoni, though the genus Stringonyx is not distinct from Machorhamphus, and thus sinks into a synonym. On the importance of the discovery of a generic form peculiar to Southwestern Africa and Malacea I need scarcely dwell, as this fact will be recognized by all my hearers.

The following is a brief synopsis of the genus as it now stands :-

\section{Genus Macharhamphus.}

Macharhamphus, Westerm. Bijd. tot d. Dierk. i. p. 29 , pl. $12(1848) \ldots \ldots \ldots \ldots \ldots \ldots \ldots$ M. alcinus. Stringonyx, Gurney, P.Z.S. 1865, p. $618 \ldots \ldots$ M. anderssoni.

\section{Clavis specierum.}

a. crista occipitali marna: abdomine brunneo. 1. alcinus.

b. crista vooipitali nulla: abdomino albo ............... 2. anderssoni.

\section{Machierhamphus alcinus.}

Macharhamphus alcinus, Westerm. Bijd. tot de Dierk. i. p. 29, pl. 12 (1848); Schl. Handl. tot de Beoef. der Dierk. i. p. 168, pl. 1. fig. 6 (1857); id. Cat. Mus. Pays-Bas, Pernes, p. 7 (1862).

M. paulo major : nigricanti-brunneus: rostro robustiore: crista occipitali longissima nigricante: regione orbitali albida: macula suborbitali conspicua alba: pectore albo, mento et striga gulari brunneis, plumis gutturalibus nonnullis etiam brunneo variis : pectore imo et abdomine toto nigricanti-brunneo.

Hab. Malacca (Maingay).

\section{Macharhamphus andersoni.}

Stringony $x$ anderssoni, Gurney, P.Z.S. 1865, p. 618.

Macharhamphus alcinus (err.), Bartlett, P.Z.S. 1866, p. 324 ; Gurney, Trans. Zool. Soc. vi. pl. 29 (1869); Gray, Hand-1. of B. i. p. $26(1869)$.

M. umbrino-brunnea : crista occipitali nulla : supercilio et striga suborbitali albis: abdomine albo, pectore medio brunneo.

Hab. Damara Land (Andersson). 
6. Descriptions of six new Humming-birds. By Јон N Goulw, F.R.S.

[Received May 16, 1871.]

The first is a species of the genus Helianthea, lately sent to this country by Mr. Henry Whitely, who is at this moment pursuing his zoological researches in Peru; the remaining five have been in my collection for some time. It will be remembered that $\mathrm{Mr}$. Whitely was also the discoverer of that highly curious and interesting Humming-bird which I charncterized in the 'Proceedings' of this Society for 1869 , p. 295 , as Oreonympha nobilis; and I would here bear testimony to the zeal and perseverance with which he is investigating the distant and almost untrodden parts of the country in which he is now located, and wherein there are doubtless many novelties yet to be discovered in every branch of zoological science.

Helianthea osculans, Gould.

Crown of the head, viewed anteriorly, black, with a spot of brilliant green on the forehead, as in II. bonapartei; back and upper tail-coverts bronzy green; shoulders golden brown; primaries purplish black, the exterior web of the first buff; throat and breast brilliant green, with a patch of an equally brilliant blue in the centre of the former; abdomen buff, tinged and mottled with green; thighs buffy white; under tail-coverts light buff; tail-feathers deep buff, tinged with green at the tip, especially the two centre ones; bill black.

Total length $5 \frac{1}{2}$ inches; bill $1 \frac{5}{8}$, wing $3 \frac{1}{8}$, tail $2 \frac{1}{8}$, tarsi $\frac{1}{4}$.

Hab. Ecachupata and Huasampilla in Peru; collected by Mr. Henry Whitely.

Remark. This new species is about the same size as $H$. violifera, but differs from that bird in having a stouter and longer bill, by the spot on the forehead being larger, and green instead of blue; by the tips of the tail-coverts and tail-feathers being tinged with olive-green, and by the breast bcing of a more brilliant green, and destitute of any crescentic greyish-white mark across the chest.

\section{Heliangelus sedamigularis, Gould.}

Bill straight and black; crown of the head, viewed anteriorly, black, posteriorly golden green; on the forehead a faint indication of a glittering spot or bar; throat shining oil-green, bordered on each side with an obscure line of black when viewed anteriorly; abdomen green; under tail-coverts grey, with green centres; thighs greenish white; toes black; upper part of the back green, passing into the brighter green of the rump and upper tail-coverts; two central tailfeathers green, the remainder black; tail slightly forked; wings purplish brown.

Total length $3 \frac{1}{4}$ inches; bill $\frac{13}{16}$, wing $2 \frac{1}{2}$, tail $1 \frac{1}{4}$.

Hab. Columbia.

Remark. I should have considered this curions bind a lusus, 
so anomalous is its colouring; but on further investigation I am induced to characterize it as distinct. Its nearest allies are Heliatrypha parzudahi and Heliangelus clarisse; but it differs from both in having a more lengthened bill, in the different colouring of its under tail-coverts, and in the unusual hue of its throat.

\section{Heliomaster albicrissa, Gould.}

Throat fiery reddish purple; crown light glistening green; upper surface and two central tail-feathers bronzy green, with the usual white mark in the centre of the back; four outer feathers on each side bronzy green, becoming nearly black towards the end, and tipped with white, the external one more largely than the others; wings purplish brown; chest grey; flanks bronzy grey; centre of the abdomen white; bill black.

Total length $4 \frac{1}{2}$ inches; bill $1 \frac{5}{8}$, wing $1 \frac{3}{8}$, tail $1 \frac{1}{2}$, tarsi $\frac{1}{4}$.

Hab. Citado in Ecuador.

Remark. Nothwithstanding the uncertainty as to whether Heliomaster longirotris, H. stuartce, H. sclateri, and H. pallidiceps are all one or so many distinct species, I feel that I have no alternative but to add to the confusion, if confusion there is, by giving the above description of a bird of the same form lately sent by Mr. Buckley from Citado in Fucador. Its size is about the same as that of $H$. longirostris and its near allies; but it differs from them all in having a still harger and longer bill and a much redder throatmark, in the white spot on the external tail-feather being longer or larger, in the lower part of the abdomen being white; in the under tail-coverts being greyish white, instead of blackish green, with lighter edges, and in the glittering feathers of the crown being of as pale, or nearly as pale a green as in the $H$. pallidiceps of Mexico. As the peculiar markings of the tail and the under tail-coverts do not occur in $\boldsymbol{H}$. longirostris of Trinidad aud some parts of Venezuela, nor in the $H$. sslateri of Costa Rica, I am induced to regard the present bird as new.

\section{Lesbia chloruira, Guuld.}

Crown of the head and all the upper surface golden green; gorget glittering green, round and well-defined as in L. gouldi; abdomen mottled green and buff, its lower portion and the under tail-coverts pure buff; wings purplish brown; the eight central tailfeathers entirely light green, the external one on each side olive, funely powdered and tipped with green, and having the outer web buff for more than half its length from the base.

Total length $6 \frac{1}{2}$ inches; bill $\frac{9}{16}$, wing 2 , tail $5 \frac{8}{8}$.

This species has all the characteristics of elegance; indeed a more graceful little creature can scarcely be conceived. It is very nearly allied to Lestia gouldi and L. gracilis, but differs from both in having a more lengthened, straighter, and greener tail, and is more especially distinguished by having a much longer and stouter bill than either of them. Its native country is supposed to be Peru. The specimen described has been in my passession for a length of 
time, but 1 have delayed characterizing it in the hope that other examples might be received.

\section{Eriocnemis russata, Gould.}

General plumage of a russet-brown; wings purplish brown; tail black; boots, or feathery covering of the thighs, rather scant for an Eriocnemis, white in front, and of a light cinnamon or deep buff posteriorly.

Total length $3 \frac{3}{4}$ inches; bill 1 , wing $2 \frac{3}{8}$, tail $1 \frac{1}{2}$.

Hab. Ecuador. Supposed to have been obtained on the banks of the Napo; but this is by no means certain ; my specimens were received from Quito.

Remark. Those Trochilidists who are acquainted with the description of the little Eriocnemis aurelice will at once perceive that the present bird is very nearly allied to, and may perhaps consider it to be identical with, that species; but when I assure them that I have carefully compared three or four examples of this bird, which is from Quito, with at least one hundred specimens of the Bogotan $E$. aurelia, they will, I trust, do me the justice to believe that $I$ have not characterized it as distinct without due consideration. The $E$. russata may at all times be distinguished by its larger size, by its russet colouring, and by its much more lengthened bill.

\section{Polytaus zeucorrhous, Gould.}

Polytmus leucorrhous, Gould, MS.; Sclat. \& Salv. in Proc. of Zool. Soc. 1867, pp. 584, 752 .

Polytmus leueoproctus, G. R. Gray, Hand-list of Birds, part i. p. 128.110 .1626$.

Male. The entire upper and under surface pale flowery green, with the exception of the head, which is brown, and the crissum, which is white; wing-coverts golden green; wing purplish brown; tail bright green ; bill light fleshy brown.

Total length $3 \frac{5}{8}$ inches; bill $\frac{3}{4}$, wing $2 \frac{1}{4}$, tail $1 \frac{1}{2}$, tarsi $\frac{3}{16}$.

Female. Much smaller than the male, but similarly coloured, except that the three outer tail-feathers on each side are tipped with white, like those of the female of Polytmus viridissimus.

For our knowledge of the existence of this species we are in. debted to the researches of A. R. Wallace, Esq., and Mr. Edward Bartlett, the former having obtained examples at Cobati, on the Rio Negro, and the latter on the river Huallaga, in Eastern Peru. It is most nearly allied to the Polytmus viridissimus of my Monograph of the 'Trochilidæ (see vol. i. Introduction, p. lxxxv, and vol. iv. pl. 231 , and 8vo edit. of Intro. p. 127), but differs from that wellknown bird in its under tail-coverts being pure white.

The specific appellation $I$ have assigned to it first appeared in Messrs. Salvin and Sclater's "List of the Birds collected by Mr. Wallace on the Lower Amazons and Rio Nigro," and subsequently in the same gentlemen's "Catalogue of Birds collected by Mr. E. Bartlett on the River Huallaga, Eastern Peru," above referred to. 